\title{
AGGRESSIVE AND NONAGGRESSIVE REJECTED STUDENTS: AN ANALYSIS OF THEIR DIFFERENCES
}

\author{
ESTEFANÍA ESTÉVEZ LÓPEZ \\ Universitat de València \\ JUAN HERRERO OLAIZOLA \\ Universidad de Oviedo \\ BELÉN MARTÍNEZ FERRER AND GONZALO MUSITU OCHOA \\ Universitat de València
}

\begin{abstract}
The present study aimed to analyze differences between aggressive and nonaggressive rejected students in four sets of variables: personal, family, school, and social. Participants in the study were 843 Spanish adolescents ranging in age from 11 to 16 years old, of whom $47 \%$ were boys. Results indicated that these two subgroups of rejected students show a different profile. Aggressive rejected students informed of lower levels of family self-esteem, less parental support, higher levels of aggression between their parents at home, and a more offensive parent-child communication in comparison with nonaggressive rejected adolescents. Moreover, aggressive rejected students showed lower levels of academic self-esteem, a more negative attitude toward school and studies, poorer relationships with teachers, and more academic difficulties than did adolescents in the nonaggressive rejected subgroup. Finally, aggressive rejected students indicated the presence of more undesirable life events and changes in their lives and, in general, higher levels of perceived stress. (C) 2006 Wiley Periodicals, Inc.
\end{abstract}

Peer acceptance and peer rejection at school refer to the degree to which students are liked or disliked in their peer group (Asher, 1990; Bierman, 2004). Numerous investigations have noted that peer acceptance is associated with students' psychosocial adjustment while peer rejection is an important source of social and emotional adjustment problems in students (Kupersmidt, Coie, \& Dodge, 1990; Pettit, Clawson, Dodge, \& Bates, 1996) such as anxiety, depression, conduct disorder, and aggression (Fergusson, Swain-Campbell, \& Horwood, 2002; Hay, Payne, \& Chadwick, 2004; Werner, 2004). Early research on peer rejection has focused precisely on the high rates of aggressive behavior that rejected students show (Bierman, Smoot, \& Aumiller, 1993); however, more recent studies have suggested that not all rejected students are aggressive and that not all aggressive students are rejected by their peers (French, 1988; Graham \& Juvonen, 2002).

Rejected students seem to be, therefore, a heterogeneous group in which at least two subgroups have been identified: aggressive rejected and nonaggressive rejected students (Harrist, Zaia, Bates, Dodge, \& Pettit, 1997). Approximately 40 to $50 \%$ of rejected students show an aggressive behavior profile which includes physical harm, psychological harm, and property damage (Astor, Pitner, Benbenishty, \& Meyer, 2002; Parkhurst \& Asher, 1992) while the other half are passive and shy (Cillesen, van IJzendoom, van Lieshout, \& Hartup, 1992; Verschueren \& Marcoen, 2002) and do not exhibit aggressiveness at school (French, 1988; Rubin, Bukowski, \& Parker, 1998).

However, while aggressive rejected students have traditionally gained the attention of researchers due probably to their higher risk for developing emotional and social adjustment problems (Miller-Johnson, Coie, Maumary-Gremaud, \& Bierman, 2002), research on nonaggressive rejected students is considerably more scant (Gifford-Smith \& Brownell, 2003). Results from prior studies

Authors' names are in alphabetical order. This investigation was supported by the Ministry of Education and Science of Spain Research Grant SEJ2004-01742. Correspondence to: Estefanía Estévez López, Departamento de Psicología Social Universidad de Valencia, Av. Blasco Ibáñez, 21, 46010 Valencia, Spain. E-mail: estefania.estevez@uv.es 
have suggested that differences among these two subgroups of rejected students may exist in the personal, family, school, and social domains (Ladd, 1999), but these have been rarely examined in the same research design. The purpose of this research was to expand knowledge in the current literature regarding differences between aggressive and nonaggressive rejected students by jointly analyzing the role of some personal, family, school, and social variables.

\section{Personal Variables}

The link between rejection at school and development of psychological problems such as depression and stress has been well established in studies both using cross-sectional (Coie, Lochman, Terry, \& Hyman, 1992) and longitudinal designs (Kiesner, 2002; Kiesner, Poulin, \& Nicotra, 2003), both for aggressive and nonaggressive rejected students (Hecht, Inderbitzen, \& Bukowski, 1998); however, nonaggressive rejected students usually obtain higher scores in measures of loneliness, shyness, and worries about being rejected again compared to aggressive rejected students (Parkhurst \& Asher, 1992).

Aggressive and nonaggressive rejected students also differ in their self-evaluations and selfesteem. For example, nonaggressive rejected students tend to report more accurate selfevaluations about their athletic, academic, and social competence when compared to aggressive rejected students, who tend to overestimate their competence in those domains-especially their social competence (Hymel, Bowker, \& Woody, 1993; Patterson, Kupersmidt, \& Griesler, 1990). Some authors have suggested that these "self-distortions" may explain why some aggressive rejected students show high levels of self-esteem in several domains. In this sense, as Sandstrom and Cramer (2003) recently reported, aggressive rejected students are particularly prone to engage in biased encoding processes that "protect" them from negative peer feedback. For example, aggressive rejected students rate their social competence as being similar to that of socially accepted students, maybe because they underestimate the extent to which they are disliked by peers (Hymel et al., 1993; Patterson et al., 1990; Zakriski \& Coie, 1996).

\section{Family Variables}

Family-peer linkage researchers have remarked that children's social behavior patterns are learned through interactions within the family: Parents influence their children's social development through modeling of social behavior and close monitoring, which allows the parents to provide teaching and reinforcement (Matza, Kupersmidt, \& Glenn, 2001; Parke, 2004). A supportive relationship with parents, for example, may provide experiences that help children learn adequate social skills that generalize to interactions with peers (Matza et al., 2001) while a low supportive relationship with parents may lead to negative interaction with peers, rejection at school, and development of behavioral problems (Patterson et al., 1990).

Other family factors such as parent-child communication and family conflicts also have been related to children's social adjustment at school. Recent studies conclude that family cohesion and openness in family communication are associated with peer acceptance at school (Gaylord, Kitzmann, \& Lockwood, 2003; Steinberg \& Morris, 2001) while offensive parent-child communication and conflict between parents are factors closely related to rejection by peers, aggressiveness at school, and children's negative attitude toward school and teachers (Barrera \& Li, 1996; Demaray \& Malecki, 2002; Estévez, Musitu, \& Herrero, 2005; Jackson \& Warren, 2000; Lambert \& Cashwell, 2003).

\section{School Variables}

Previous research has shown that rejected students are, in general, more at risk for academic difficulties and school failure than those students not rejected by their peers (Hatzichristou \& 
Hopf, 1996). This especially seems to be the case for aggressive rejected students, who have less motivation toward school success and studies (Wentzel \& Asher, 1995). Some authors also have shown that aggressive adolescents show a more negative attitude toward school and studies (Adair, Dixon, Moore, \& Sutherland, 2000; Emler \& Reicher, 1995), which could explain, at least in part, academic failure and lack of motivation of these students.

Furthermore, within the school context, teachers also play an important role in students' academic success as well as in their social adjustment in the classroom (Hamre \& Pianta, 2001; Murray \& Greenberg, 2001; Zettergren, 2003). On one hand, as Davis (2003) suggested, the quality and supportive teacher-student relationship may motivate students to achieve academic goals; however, the quality of the teacher's relationship with rejected students is usually lower than with students socially accepted by their peers (Blankemeyer, Flannery, \& Vazsonyi, 2002), and even lower with aggressive rejected students (Birch \& Ladd, 1998). On the other hand, teachers also may affect social relationships in the classroom since teacher's beliefs, expectations, and perceptions influence students' beliefs, expectations, peer preferences, and perceptions in relation to rejected classmates (Birch \& Ladd, 1998; Zettergren, 2003).

\section{Social Variables}

Research analyzing friendships and peer networks of rejected children has found that the peer friendship networks of rejected students are usually smaller in comparison with students with other social status (Bagwell, Coie, Terry, \& Lochman, 2000); however, as far as friendship quality is concerned, no differences have been found between rejected students and their friends versus nonrejected students and their friends (Brendgen, Little, \& Krappmann, 2000). In fact, over half of rejected students have at least one reciprocal best friend (Parker \& Asher, 1993) whose support could compensate for some of the deleterious consequences of peer rejection (Brendgen et al., 2000).

With reference to aggressive rejected students, although they usually inform about the presence of more conflicts with their friends (Patterson et al., 1990), they also are often important figures in their peer group and therefore tend to enjoy benefits of social inclusion (Hawley \& Vaughn, 2003). In this sense, as Gifford-Smith and Brownell (2003) reported, aggressive behavior, while strongly related to peer rejection, appears to be positively related to group centrality.

\section{Aim of the Current Study}

Taking into account all of the aforementioned findings and given that research focused on differences between aggressive and nonaggressive rejected students is really scant, the purpose of the present study was to examine differences between these two subgroups of rejected students in the following four sets of variables: personal, family, school, and social. Personal variables included self-esteem, depressive symptomatology, and perceived stress. Family variables comprise parentchild communication, perceived parental support, and aggression between parents. School variables include academic success, teacher-student relationship, and attitude toward school and teachers. Finally, social variables include best friend support, boy/girlfriend support, and the presence of undesirable life events and changes within the last year.

Based on findings from previous studies, it was expected that aggressive rejected students, compared to nonaggressive rejected students would: (a) show lower academic and family self-esteem, higher social self-esteem, and the same level of depression and perceived stress; (b) perceive more problems in parent-child communication, less parental support, and more aggression between parents; (c) show more academic difficulties, lower quality relationships with teachers, and more negative attitudes toward school and teachers; and (d) perceive more social support from friends, but also more undesirable life events and changes in their lives. 


\section{MethoD}

\section{Participants}

Participants in the study were 1,068 Spanish adolescents attending secondary education at the time of the research, of whom 843 provided complete data for all study variables. Age ranged from 11 to 16 years (mean age $=13.7$ ), and gender was distributed approximately equal in the sample: $47 \%$ boys and $53 \%$ girls. For age analyses, we split two age groups corresponding with the early adolescence (11- to 13-year-olds) and the middle adolescence (14- to 16-year-olds).

\section{Measures and Instruments}

Next we present the instruments used in this study. Some were back-translated to Spanish, and others were originally developed in Spanish in previous research. Finally, some instruments were designed for this study. All directions were written in Spanish. Although we previously analyzed the factor structure of all scales to further ascertain if they replicated the original scales, in this section we only present results for (a) those scales whose factor structure was not replicated in our data or (b) those scales that were originally created for this research (with the exception of the Teacher's Perception of Student Scale that consisted of only two items). Criteria for principal components extraction was eigenvalue 1 .

Self-Esteem Multidimensional Scale. We used the family, academic, and social subscales of the Self-Esteem Form A Scale (AFA; Musitu, García, \& Gutiérrez, 1994). The AFA has been widely used in the Spanish population and provides information about the adolescent's family self-esteem (e.g., "I feel happy at home"), academic self-esteem (e.g., "I'm a good student"), and social self-esteem (e.g., "It's easy for me to find new friends") on a 3-point scale ( $1=$ never, $2=$ sometimes, and $3=$ always). Cronbach's $\alpha$ reliability for these subscales in the present study was $.79, .86$. , and .76 respectively.

Center of Epidemiological Studies Depression Scale (CESD; Radloff, 1977). The CESD is a 20-item scale which evaluates the presence of depressive symptomatology including the following dimensions: depressed mood, positive affect, somatic and retarded activity, and interpersonal distress. It also provides a global measure of depressive mood, used in this study. Responses are rated on a scale of 1 (never) to 4 (always) (e.g., "I was bothered by things that usually don't bother me"). Cronbach's $\alpha$ reliability for this scale in the present study was .90 .

Perceived Stress Scale (PSS; Cohen, Kamarck, \& Mermelstein, 1983). The PSS is a 14-item scale which measures the degree to which respondents appraised situations as stressful within the last month on a scale of 1 (never) to 5 (very often) (e.g., "In the last month, how often have you found that you could not cope with all the things that you have to do?"). Coefficient $\alpha$ in the current sample for this scale was .82.

Father-Mother Aggression Scale. This is a four-item scale designed for the present study to measure the presence of aggression between parents at home on a scale of 1 (never) to 5 (always). Principal component analysis with varimax rotation yielded a two-factor structure: physical aggression (explained variance $=36.1 \%$, Cronbach's $\alpha=.85$ ) (e.g., "My father pushes my mother") and verbal aggression (explained variance $=32 \%$, Cronbach's $\alpha=.80$ ) (e.g., "My mother insults my father").

Parent-Adolescent Communication Scale (PACS; Barnes \& Olson, 1982). In this 20-item scale, adolescents describe the communication with their parents on a scale of 1 (never) to 5 (always). The original scale showed a two-factor structure referring to degree of openness and extent of problems in family communication (coefficients $\alpha=.87$ and .78, respectively; test-retest 
reliabilities $=.78$ and .77 , respectively); however, as with other authors in recent studies (see Feldman \& Rosenthal, 2000), we could not replicate this factor structure in our data. Principal component analysis with varimax rotation yielded a three-factor structure for father and mother separately. The first factor explained $30.66 \%$ of variance and grouped 10 items referring to open communication with parents (e.g., My mother/father is a good listener"). The second factor explained $21.85 \%$ of variance and grouped six items referring to offensive communication with parents (e.g., My mother/father insults me when she/he is angry with me"). Finally, the third factor explained $9.52 \%$ of variance and grouped four items referring to avoidant communication with parents (e.g., "I am sometimes afraid to ask my mother/father for what I want"). Cronbach's reliability coefficients for these subscales were $.87, .76$, and .75 , respectively.

Relational Support Inventory (RSI; Scholte, van Lieshout, \& van Aken, 2001). Perceived support from parents, best friend, and boy/girlfriend was assessed using this 27 -item scale which measures the following four dimensions: emotional support (e.g., "In this person's view, I can't do anything right: $\mathrm{He} / \mathrm{she}$ is always criticizing me;" reverse coded), informational support (e.g., "This person explains or shows how I can make or do something"), respect for autonomy (e.g., "This person lets me solve problems as much as possible on my own but also provides help when I ask for it"), and convergence of goals (e.g., "This person and I have many conflicts with regard to school achievement, the future, or career opportunities;" reverse coded). For each source of support (i.e., parents, best friend, and boy/girlfriend), scores on the four dimensions were added. Cronbach's $\alpha$ reliability was: .83 for parental support, .94 for best friend support, and .97 for boy/girlfriend support.

Adolescent-Family Inventory of Life Events and Changes (A-FILE; McCubbin \& Thompson, 1991). The A-FILE is a 50-item instrument designed to measure normative and nonnormative life events and changes experienced within the past year by members of the adolescent's nuclear family (e.g., "Death of a family member"). Test-retest reliabilities have been reported to range from .64 to .84 (McCubbin \& Thompson, 1991).

Attitude Towards Institutional Authority Scale. Some items of a previous scale from Reicher and Emler (1985) were adapted to measure participants' attitude to formal authority. The scale used in this study consists of 28 items rated on a scale of 1 (I totally disagree) to 4 (I totally agree) referring to attitude toward teachers, school, and social rules. This scale showed a four-factor structure using principal component analysis: The first factor explained $15.71 \%$ of variance and grouped six items referring to positive attitude toward formal authority (e.g., "I agree with what my teachers say and do"); the second factor explained $14.91 \%$ of variance and grouped four items referring to positive attitude toward transgression of social rules (e.g., "It is usual to disobey teachers if there is not any punishment"); the third factor explained $11.74 \%$ of variance and grouped four items referring to perception of injustice in the way authority figures behave (e.g., "Teachers only take care of students with good marks"); and finally, the fourth factor explained $10.11 \%$ of variance and grouped three items referring to indifference toward studies and school (e.g., "I would prefer a job instead of studying"). Cronbach's reliability coefficients for these subscales were $.77, .73, .72$, and .71 , respectively.

School Violence Scale. Aggressive behavior at school was assessed using the Violence at School Scale (Herrero, Estévez, \& Musitu, in press). This 13-item scale measures the frequency with which students engaged in 13 violent behaviors at school (verbal and physical aggression as well as disruptive behavior in the classroom) during the past 12 months on a six-point scale $(0=$ I don't want to share this information, $1=$ never, $5=$ many times) (e.g., "I got into fights at school"). Approximately $7 \%$ of respondents chose not to inform of the content of some items 
marking " 0 ;" these subjects were removed from the analyses. We used the global score to classify control, aggressive, and nonaggressive students. Cronbach's $\alpha$ coefficient for this scale was .87 .

Sociometric Questionnaire. This instrument allows the discovery of the basic structure of relationships of a group. This kind of questionnaire is not a standardized one; rather, it is prepared by the researcher following specific criteria for the group whose structure of relationships is being studied. In the present study, this scale was used to obtain information about the social structure of interactions between students of the same classroom. The questionnaire was comprised of four items, grouped in accordance with the sociometric criteria "teamwork." Participants were asked to give positive selections ("With whom would you prefer to ...?"), negative selections ("With whom would you prefer not to ... ?"), perceptions of positive selection ("Who do you think has chosen you?"), and perceptions of negative selection ("Who do you think hasn't chosen you?"). The method was nominative with limited possibility of choice (three classmates) and in order of preference. The positive and negative nominations received from peers provided indexes of peer acceptance and peer rejection, respectively. Following Coie, Dodge, and Coppotelli's procedure (1982), an index of social preference was formed by subtracting nominations scores.

Teacher's Perception of Students. In Spanish schools, there is a head instructor for each classroom who spends more time with students than other teachers from the school staff. Fortyfour head instructors were asked to estimate academic success and quality of teacher-student relationship for each student in his/her classroom on a scale of 1 (very bad) to 10 (very good) (teachers' response rate $=100 \%$ ).

Data on school violence were compared with available national statistics (Informe del Defensor del Pueblo, 2002). Overall, results indicated that the four selected schools showed similar levels of aggression as compared with Spanish adolescents, suggesting that these schools were representative of the Spanish adolescent population (for a more detailed description, see Herrero et al., in press).

As for the validity of the measures used in the study, previous research has shown adequate predictive validity for most of the scales. For instance, higher levels of family, academic, and social self-esteem have been associated with lower levels of psychological distress and measures of family functioning (Musitu \& García, 2004; Musitu et al., 1994). The CESD has been validated and used in many previous studies with adolescent participants (Wiesner \& Windle, 2004). Regarding the use of CESD in a Spanish population, there is empirical evidence that a higher score is associated with higher levels of perceived stress in adolescents (Estévez et al., 2005) and college students (Herrero \& Meneses, in press). For the PSS, previous research has shown that higher scores are associated with lower self-esteem and lower social support (Gracia \& Herrero, 2004). The three dimensions of the PACS also have been found to be significantly associated with several outcomes in a Spanish adolescent population. For instance, Estévez et al. (2005) found that lower scores in open communication and higher scores in offensive and avoidant communication were associated with higher levels of psychological distress, a poorer relationship with teacher, and higher levels of school-based aggressive behavior toward peers. In addition, Herrero et al. (in press) reported that older adolescents and boys show lower scores in communication with parents.

The RSI measure of social support has been found to be positively associated with personal adjustment in adolescence (Branje, van Aken, \& Lieshout, 2002; Scholte et al., 2001) and negatively with psychological distress in the Spanish adolescent population (Herrero et al., in press). The Father-Mother Aggression Scale has been used in previous investigations (e.g., Estévez \& Musitu, 2004), in which higher levels of aggression between parents were found to be related to higher levels of aggressiveness in children. The Attitude Towards Institutional Authority Scale also has shown a significant association with higher levels of aggression and violence

Psychology in the Schools DOI: 10.1002/pits 
in adolescence (Emler \& Reicher, 1995). Finally, the A-FILE measure of life events and changes has shown an association with health problems (DeMarco, Ford-Gilboe, Friedemann, McCubbin, \& McCubbin, 2000).

\section{Procedure}

Data for this research were collected as part of a larger study on adolescent problem behavior at school. Four schools from a large urban area in Valencia, Spain participated in the study because of their availability and based on their school staff predisposition of voluntary participation. All these schools are semipublic secondary schools with free education; this is the type of school most common in the Valencian community. Students in these schools have a middle-low, middle, or middle-high socioeconomic status.

Teachers were informed of the objectives of the study during a 2-hr presentation. In parallel, a letter describing the study was sent to the parents who had to indicate in writing if they did not wish their child to participate in the study. Participants anonymously filled out the scales during a regular class period lasting approximately $1 \mathrm{hr}$. All measures were administered within each classroom on the same day.

To complete the sociometric questionnaire, students were provided a class roster. To preserve anonymity of students' responses, each name was assigned a number and students were instructed to complete the sociometric questionnaire by writing the numbers instead of the names of classmates. Students also were asked to write their own number on the top of the questionnaire and were told to not write their name on the response sheets. Students were instructed to keep their answers private and were given sheets to cover their responses.

\section{RESULTS}

Univariate and multivariate analyses of variance (ANOVA and MANOVA) were conducted to test differences in the variables included in the study among the following three groups: aggressive rejected students $(n=43)$, nonaggressive rejected students $(n=127)$, and a control group of nonaggressive nonrejected students $(n=673)$. Rejected students were identified by means of the Sociometric Questionnaire. Raw scores on the School Violence Scale were standardized within each classroom. Students with scores $1 S D$ above the classroom mean $(z \geq 1)$ were labeled as aggressive. This cutoff criteria of $1 S D$ was selected in accordance with previous research using this same strategy (see Coie et al., 1982). Other researchers have used a less stringent criteria (e.g., the $0.5 S D$ criteria used by Schwartz, 2000) when extreme scores on both aggression and victimization are small, and as a result, empty cells may be expected in cross-group comparisons. Due to our relatively large sample size, the cutoff criteria of $1 S D$ seemed appropriate.

Prior to comparisons between groups, several analyses were carried out to obtain a better understanding of the distribution by gender and age of the rejected and aggressive students in the sample. There were more aggressive boys than girls, $\chi^{2}=44.70, d f=1, p<.001$, but the percentage of rejected boys and girls was not statistically different, $\chi^{2}=3.28, d f=1, p=.070$. Regarding age groups, the percentage of rejected students, $\chi^{2}=3.31, d f=1, p=.069$, and aggressive students, $\chi^{2}=1.77, d f=1, p=.183$, were equally distributed in the two age groups studied (11- to 13-, and 14- to 16-year-olds). None of the schools included in this study showed a different significant proportion of aggressive, $\chi^{2}=3.28, d f=3, p=.070$, or rejected, $\chi^{2}=3.28$, $d f=3, p=.070$, students.

Following these preliminary analyses, a MANOVA was conducted across all personal, family, school, and social variables to examine group differences among aggressive rejected, nonaggressive rejected, and the control group of nonaggressive nonrejected adolescents. Next, a post 
Table 1

Personal Variables: Means, SDs (in parentheses), and Bonferroni-Adjusted Mean Differences for Control, Nonaggressive, and Aggressive Rejected Students

\begin{tabular}{llll}
\hline & \multicolumn{3}{c}{ Rejected } \\
\cline { 2 - 4 } Variable & Control Group & Nonaggressive & Aggressive \\
\hline Academic self-esteem & $21.21^{\mathrm{a}}(4.49)$ & $19.24^{\mathrm{b}}(4.46)$ & $15.69^{\mathrm{c}}(4.45)$ \\
Family self-esteem & $26.20^{\mathrm{a}}(3.82)$ & $25.51^{\mathrm{a}}(4.21)$ & $23.67^{\mathrm{b}}(3.87)$ \\
Social self-esteem & $23.93^{\mathrm{a}}(3.63)$ & $22.92^{\mathrm{b}}(4.28)$ & $23.95^{\mathrm{a}}(3.79)$ \\
Depressive symptoms & $48.15^{\mathrm{b}}(15.60)$ & $50.51^{\mathrm{a}}(14.32)$ & $50.90^{\mathrm{a}}(13.20)$ \\
Perceived stress & $38.28^{\mathrm{b}}(9.24)$ & $38.93^{\mathrm{b}}(8.90)$ & $41.30^{\mathrm{a}}(8.46)$ \\
\hline
\end{tabular}

$\mathrm{a}>\mathrm{b}>\mathrm{c} ; \mathrm{p}<.05$

hoc ANOVA (using Bonferroni correction) was carried out individually for each variable statistically significant in the MANOVA. Due to the existence of sharply unequal cell sizes, Brown and Forsythe (1974) and Welch (1951) robust estimators to account for the violation of homogeneity of variances were used for the calculation of the $F$ in the ANOVA.

Regarding personal variables (Wilks's $\Lambda=.859, p<.001$, size effect $\eta^{2}=.05$ ) as seen in Table 1, aggressive rejected students showed the lowest levels of academic and family self-esteem as well as higher levels of perceived stress when compared to nonaggressive rejected students and to the control group. However, results did not show a significant difference between aggressive rejected students and the control group in social self-esteem; in this case, nonaggressive rejected students obtained the lowest score. Finally, both groups of rejected students showed more depressive symptoms than the control group.

As for family variables (Wilks's $\Lambda=.898, p<.001$, size effect $\eta^{2}=.03$ ), shown in Table 2, aggressive rejected students perceived less parental support in comparison with nonaggressive rejected students and especially with the control group. Moreover, aggressive rejected students perceived more aggression between their parents at home (both physical and verbal) and communication with them as more offensive and avoidant when compared to the other two groups, which scored higher in the measure of open parent-child communication.

Table 2

Family Variables: Means, SDs (in parentheses), and Bonferroni-Adjusted Mean Differences for Control, Nonaggressive, and Aggressive Rejected Students

\begin{tabular}{lccr}
\hline & \multicolumn{3}{c}{ Rejected } \\
\cline { 2 - 4 } Variable & Control Group & Nonaggressive & Aggressive \\
\hline Parental Support & $60.80^{\mathrm{a}}(12.21)$ & $57.70^{\mathrm{b}}(14.21)$ & $53.30^{\mathrm{c}}(14.05)$ \\
Parent-Child Communication & & & \\
Open communication & $16.42^{\mathrm{a}}(2.97)$ & $16.12^{\mathrm{a}}(3.23)$ & $15.02^{\mathrm{b}}(3.26)$ \\
Offensive communication & $6.63^{\mathrm{b}}(3.05)$ & $7.37^{\mathrm{b}}(3.51)$ & $8.30^{\mathrm{a}}(4.05)$ \\
Avoidant communication & $6.61^{\mathrm{b}}(2.21)$ & $6.35^{\mathrm{b}}(2.42)$ & $7.72^{\mathrm{a}}(2.29)$ \\
Father-Mother Aggression & & & \\
Physical aggression & $4.16^{\mathrm{b}}(1.14)$ & $4.21^{\mathrm{b}}(0.87)$ & $4.86^{\mathrm{a}}(1.12)$ \\
Verbal aggression & $7.09^{\mathrm{b}}(3.33)$ & $7.21^{\mathrm{b}}(3.69)$ & $8.35^{\mathrm{a}}(4.23)$ \\
\hline
\end{tabular}

$\mathrm{a}>\mathrm{b}>\mathrm{c} ; p<.05$. 
Table 3

School Variables: Means, SDs (in parentheses), and Bonferroni-Adjusted Mean Differences for Control, Nonaggressive, and Aggressive Rejected Students

\begin{tabular}{lrrr}
\hline & \multicolumn{3}{c}{ Rejected } \\
\cline { 2 - 4 } Variable & Control Group & Nonaggressive & Aggressive \\
\hline Teacher's perception & $6.79^{\mathrm{a}}(2.30)$ & $4.86^{\mathrm{b}}(2.63)$ & $4.00^{\mathrm{c}}(2.28)$ \\
$\quad$ Academic success & $7.40^{\mathrm{a}}(1.47)$ & $6.62^{\mathrm{b}}(1.62)$ & $6.14^{\mathrm{c}}(1.61)$ \\
Teacher-student relationship & & & \\
Attitude toward authority & $6.44^{\mathrm{b}}(2.61)$ & $6.81^{\mathrm{b}}(2.91)$ & $9.16^{\mathrm{a}}(3.86)$ \\
Positive attitude transgression & $16.49^{\mathrm{a}}(3.96)$ & $16.65^{\mathrm{a}}(3.87)$ & $13.83^{\mathrm{b}}(3.29)$ \\
Positive attitude authority & $8.14^{\mathrm{b}}(2.84)$ & $8.66^{\mathrm{b}}(2.74)$ & $10.37^{\mathrm{a}}(3.05)$ \\
Perception of injustice & $4.28^{\mathrm{c}}(1.72)$ & $4.77^{\mathrm{b}}(1.95)$ & $6.18^{\mathrm{a}}(1.73)$ \\
Indifference toward studies & & & \\
\hline
\end{tabular}

$\mathrm{a}>\mathrm{b}>\mathrm{c} ; p<.05$.

With reference to school variables (Wilks's $\Lambda=.948, p<.001$, size effect $\eta^{2}=.08$ ), presented in Table 3, results indicated that teachers perceived students in the control group as those having more academic success and perceived the group of aggressive rejected students as the one less academically successful. In addition, teachers informed of having a better teacher-student relationship with students in the control group than with rejected students, and especially with the group of aggressive rejected.

Furthermore, aggressive rejected students scored significantly higher than any other group on the measures referring to a negative attitude toward institutional authority. In this sense, they informed of having a positive attitude toward transgression of social rules, perceived more injustice at school, and were more indifferent toward their studies. They expressed, overall, the lowest levels of respect toward formal authority. On the other hand, there were more similarities between the control and nonaggressive groups: similar levels of attitude toward transgression, respect toward authority, and perception of injustice. Nonaggressive rejected students, however, showed more indifference toward studies than students in the control group.

Finally, regarding social variables (Wilks's $\Lambda=.954, p<.001$, size effect $\eta^{2}=.03$ ), as seen in Table 4, there were no significant differences among groups in perceived best-friend support. The aggressive rejected group, however, showed the highest levels of perceived boy/girlfriend support in comparison with both the control and the nonaggressive groups. On the other hand,

Table 4

Social Variables: Means, SDs (in parentheses), and Bonferroni-Adjusted Mean Differences for Control, Nonaggressive, and Aggressive Rejected Students

\begin{tabular}{lccc}
\hline & \multicolumn{3}{c}{ Rejected } \\
\cline { 2 - 4 } Variable & Control Group & Nonaggressive & Aggressive \\
\hline Friend's support (n.s.) & $54.20(16.88)$ & $51.56(17.77)$ & $50.51(20.40)$ \\
Boy/girlfriend support & $17.01^{\mathrm{b}}(28.16)$ & $18.54^{\mathrm{b}}(28.85)$ & $31.23^{\mathrm{a}}(30.11)$ \\
Life Events & $5.67^{\mathrm{c}}(3.68)$ & $6.74^{\mathrm{b}}(4.53)$ & $8.95^{\mathrm{a}}(5.19)$
\end{tabular}

$\mathrm{a}>\mathrm{b}>\mathrm{c} ; p<.05$. 
students in the control group indicated that they had experienced less undesirable life events and changes in their families within the last year compared with the two groups of rejected students, especially with aggressive rejected students.

\section{DISCUSSION}

The present study aimed to investigate differences between aggressive and nonaggressive rejected students in relation to several personal, family, school, and social variables. As expected, these two subgroups of rejected students presented a different profile in the four domains analyzed.

As expected, results regarding personal variables showed that aggressive rejected students informed of lower academic and family self-esteem, but of higher social self-esteem, in comparison to nonaggressive rejected students. In other words, nonaggressive rejected students showed more positive self-evaluations in the academic and family domains whereas aggressive rejected students perceived themselves as more socially competent. These findings are in line with those reporting that aggressive rejected students tend to overestimate their competence in some domains, such as their social competence (Hymel et al., 1993; Patterson et al., 1990). Other studies have found that some aggressive rejected students are not aware of their social status (Zakriski \& Coie, 1996) while nonaggressive rejected students seem to be more realistic about their social situation at school, and consequently, they have less positive beliefs about their peers (Rabiner, Keane, \& MacKinnon-Lewis, 1993). Moreover, friends of aggressive rejected students are usually students with the same social status or better (e.g., popular status) (Gifford-Smith \& Brownell, 2003), which also contributes to the explanation why they have a good self-perception of their social relationships.

As for depression and stress, it was expected that aggressive and nonaggressive rejected students would show the same level of depressive symptoms and perceived stress. Results indicated that both subgroups of rejected students inform of the presence of depressive symptoms in a similar way, but that aggressive rejected students perceive more stress when compared to the nonaggressive rejected students. In this sense, Hecht et al. (1998) did not find significant differences in global scores of depression between aggressive and nonaggressive rejected students; however, they considered that depression had a different origin in these subgroups of rejected adolescents. In particular, these authors suggested that depressive symptomatology depended on the nature of peer difficulties: For aggressive rejected students, the cause of depression would be interpersonal problems with peers, which also could increase levels of perceived stress; for nonaggressive rejected students, the reason would be their lower levels of social interactions.

Aggressive and nonaggressive rejected students also differed in the family variables analyzed, and in the expected direction: Aggressive rejected students perceived less parental support, more aggression between parents at home (both physical and verbal), and a more negative parentchild communication in comparison with nonaggressive rejected students. These results are consistent with research documenting that problems in family functioning are closely linked to later peer acceptance at school (Gaylord et al., 2003; Gifford-Smith \& Brownell, 2003; Steinberg \& Morris, 2001; Woodward \& Fergusson, 1999) and aggression (Demaray \& Malecki, 2002; Herrero et al., in press; Lopez \& Dubois, 2005). Some authors have stressed the influence of family socialization on children's peer relations since socialization in the family context makes children learn certain social skills which will guide their social interactions in other contexts, such as the school context (Eisenberg et al., 2003; Parke, 2004). Related to this, our results suggest that the family context of aggressive rejected students is characterized by mutual parental aggression, by negative parent-child communication, and by lack of support from parents; this negative context of socialization may lead adolescents to learn that aggression is the best or the only way to resolve conflicts with peers. 
Regarding school variables, aggressive rejected students showed more academic difficultieswhich could explain why they also had lower levels of academic self-esteem-and poorer relationships with teachers. These results are in line with previous studies showing that both rejected and aggressive children are less successful at school (Hatzichristou \& Hopf, 1996; Wentzel \& Asher, 1995) and usually have conflictual relationships with teachers (Murray \& Murray, 2004). In addition, the subgroup of aggressive rejected students informed of a more negative attitude toward school, more indifference toward studies, and a higher perception of injustice in relation to the way teachers and, in general, the school context treat them. We are not aware of other studies comparing attitude toward school among subgroups of rejected students, although some research has examined the link between aggression at school and attitude toward this institution. Findings from these investigations suggest that a negative attitude toward formal authority (e.g., school and teachers) determines and could even predict behavioral problems in adolescence (Hoge, Andrews, \& Leschied, 1996; Loeber, 1996) whereas a positive attitude toward school is negatively related to aggressive behavior (Moncher \& Miller, 1999; Thornberry, 1996).

Finally, with reference to social variables, aggressive rejected students were expected to perceive more undesirable life events, but also more social support; these results have been confirmed by our data. Aggressive rejected students informed of the presence of more undesirable life events and changes in their lives than did nonaggressive rejected students, which could be why they also perceived more stress. Findings regarding support from friends indicated that aggressive and nonaggressive rejected students perceived similar levels of a best-friend's support, and that aggressive rejected students perceived even more support from a girl/boyfriend. These results suggest that although rejected students have smaller friendship networks than children socially accepted at school (Bagwell et al., 2000), they perceive higher levels of support from these friends. As Gest, Graham-Bermann, and Hartup (2001) recently reported, almost $40 \%$ of rejected students have a best friend, which could explain why rejected students do not necessarily report lower levels of perceived social support. Research considering girl/boyfriend support is very scant, so it could be interesting to include this variable in future investigations.

As for the limitations of the study, some of the measures used are self-reported and thus allowed for potential shared-method variance. Although data in the present study were collected from different sources (i.e., adolescents, their classmates, and their teachers), response bias might impact the validity and the generalizability of the study findings. It would be desirable in future research to obtain additional data from parents (e.g., regarding perception of family communication and aggression between father/mother at home) to better understand the associations analyzed in this study. Moreover, and given that previous research has suggested that father and mother may affect child's adjustment in different ways (Kim, Hetherington, \& Reiss, 1999), future investigation should separately consider perceived support from father and mother. Finally, the present study used a cross-sectional design, but the use of longitudinal data would help to further clarify differences among subgroups of rejected students.

In conclusion, the current study contributes to our understanding of the differences between aggressive and nonaggressive rejected students in some individual, family, social, and school variables. In this sense, this research is one of the few in which multiple variables are jointly analyzed to search for similarities and differences between aggressive and nonaggressive rejected students.

\section{REFERENCES}

Adair, V.A., Dixon, R.S., Moore, D.W., \& Sutherland, C.M. (2000). Bullying in New Zealand secondary schools. New Zealand Journal of Educational Studies, 35, 207-221. 
Asher, S. (1990). Recent advances in the study of peer rejection. In S.R. Asher \& J.D. Coie (Eds.), Peer rejection in childhood (pp. 3-14). New York: Cambridge University Press.

Astor, R., Pitner, R.O., Benbenishty, R., \& Meyer, H.A. (2002). Public concern and focus on school violence. In L.A. Rapp-Paglicci, A.R. Roberts, \& J.S. Wodarski (Eds.), Handbook of violence (pp. 262-297). New York: Wiley.

Bagwell, C.L., Coie, J.D., Terry, R.A., \& Lochman, J.E. (2000). Peer clique participation and social status in preadolescence. Merrill-Palmer Quarterly, 46, 309-323.

Barnes, H.L., \& Olson, D.H. (1982). Parent-adolescent communication scale. In H.D. Olson (Ed.), Family inventories: Inventories used in a national survey of families across the family life cycle (pp. 33-48). St. Paul: University of Minnesota Press.

Barrera, M.J., \& Li, S.A. (1996). The relation of family support to adolescents' psychological distress and behavior problems. In G.R. Pierce \& I.G. Sarason (Eds.), Handbook of social support and the family (pp. 313-343). New York: Plenum Press.

Bierman, K.L. (2004). Peer rejection. Developmental processes and intervention strategies. New York: Guilford Press.

Bierman, K.L., Smoot, D.L., \& Aumiller, K. (1993). Characteristics of aggressive-rejected, aggressive (nonrejected), and rejected (nonaggressive) boys. Child Development, 64, 139-151.

Birch, S.H., \& Ladd, G.W. (1998). Children's interpersonal behaviors and the teacher-child relationship. Developmental Psychology, 34, 934-946.

Blankemeyer, M., Flannery, D.J., \& Vazsonyi, A.T. (2002). The role of aggression and social competence in children's perception of the child-teacher relationship. Psychology in the Schools, 39, 293-304.

Branje, S.J.T., van Aken, M.A., \& van Lieshout, C.F.M. (2002). Relational support in families with adolescents. Journal of Family Psychology, 16, 351-362.

Brendgen, M., Little, T.D., \& Krappmann, L. (2000). Rejected children and their friends: A shared evaluation of friendship quality? Merrill-Palmer Quarterly, 46, 45-70.

Brown, M.B., \& Forsythe, A.B. (1974). The small sample behavior of some statistics which test the equality of several means. Technometrics, 16, 129-132.

Cillesen, A., van IJzendoom, H., van Lieshout, C., \& Hartup, W. (1992). Heterogeneity among peer rejected boys: Subtypes and stabilities. Child Development, 63, 893-905.

Cohen, S., Kamarck, T., \& Mermelstein, R. (1983). A global measure of perceived stress. Journal of Health and Social Behavior, 24, 385-396.

Coie, J.D., Dodge, K.A., \& Coppotelli, H. (1982). Dimensions and types of social status: A cross-age perspective. Developmental Psychology, 18, 557-570.

Coie, J.D., Lochman, J.E., Terry, R., \& Hyman, C. (1992). Predicting early adolescent disorder from childhood aggression and peer rejection. Journal of Consulting and Clinical Psychology, 60, 783-792.

Davis, H. (2003). Conceptualizing the role and influence of student-teacher relationships on children's social and cognitive development. Educational Psychologist, 38, 207-234.

Demaray, M.P., \& Malecki, C.K. (2002). The relationship between perceived social support and maladjustment for students at risk. Psychology in the Schools, 39, 305-316.

DeMarco, R., Ford-Gilboe, M., Friedemann, M., McCubbin, H.I., \& McCubbin, M.A. (2000). Stress, coping, and family health. In V.H. Rice (Ed.), Handbook of stress, coping and health (pp. 295-332). Thousand Oaks, CA: Sage.

Eisenberg, N., Fabes, R.A., Shepard, S.A., Guthrie, I.K., Murphy, B.C., \& Reiser, M. (2003). Parental reactions to children's negative emotions: Longitudinal relations to quality of children's social functioning. Child Development, 70, 513-534.

Emler, N., \& Reicher, S. (1995). Adolescence and delinquency. Oxford, England: Blackwell.

Estévez, E., \& Musitu, G. (2004, May). Parental support, family relationships and social adjustment at school in adolescence. Paper presented at the IX Conference of the European Association for Research on Adolescence (EARA), O Porto (Portugal).

Estévez, E., Musitu, G., \& Herrero, J. (2005). The influence of violent behavior and victimization at school on psychological distress: The role of parents and teachers. Adolescence, 40, 183-195.

Feldman, S.S., \& Rosenthal, D.A. (2000). The effect of communication characteristics on family members' perceptions of parents as sex educators. Journal of Research on Adolescence, 10, 119-150.

Fergusson, D.M., Swain-Campbell, N.R., \& Horwood, L.J. (2002). Deviant peer affiliations, crime and substance use: A fixed effects regression analysis. Journal of Abnormal Child Psychology, 30, 419-430.

French, D. (1988). Heterogeneity of peer-rejected boys: Aggressive and nonaggressive sub-types. Child Development, 59, 976-985.

Gaylord, N.K., Kitzmann, K.M., \& Lockwood, R.L. (2003). Child characteristics as moderators of the association between family stress and children's externalizing, and peer rejection. Journal of Child and Family Studies, 12, 201-213.

Gest, S.D., Graham-Bermann, S.A., \& Hartup, W.W. (2001). Peer experience: Common and unique features of number of friendships, social network centrality, and sociometric status. Social Development, 10, 23-40.

Psychology in the Schools DOI: $10.1002 /$ pits 
Gifford-Smith, M.E., \& Brownell, C.A. (2003). Childhood peer relationships: Social acceptance, friendships, and social network. Journal of School Psychology, 41, 235-284.

Gracia, E., \& Herrero, J. (2004). Personal and situational determinants of relationship-specific perceptions of social support. Social Behavior and Personality, 32, 459-476.

Graham, S., \& Juvonen, J. (2002). Ethnicity, peer harassment, and adjustment in middle school: An exploratory study. Journal of Early Adolescence, 22, 173-199.

Hamre, B.K., \& Pianta, R.C. (2001). Early teacher-child relationships and the trajectory of children's school outcomes through eighth grade. Child Development, 72, 625-638.

Harrist, A.W., Zaia, A.F., Bates, J.E., Dodge, K.A., \& Pettit, G.S. (1997). Subtypes of social withdrawal in early childhood: Sociometric status and social-cognitive differences across four years. Child Development, 68, 278-294.

Hatzichristou, C., \& Hopf, D. (1996). A multiperspective comparison of peer sociometric status groups in childhood and adolescence. Child Development, 67, 1085-1102.

Hawley, P., \& Vaughn, B. (2003). Aggression and adaptation: The bright side to bad behavior. Merrill-Palmer Quarterly, 49, 239-244.

Hay, D.F., Payne, A., \& Chadwick, A. (2004). Peer relations in childhood. Journal of Psychology and Psychiatry, 45, 84-108.

Hecht, D.B., Inderbitzen, H.M., \& Bukowski, A.L. (1998). The relationship between peer status and depressive symptoms in children and adolescents. Journal of Abnormal Child Psychology, 26, 153-160.

Herrero, J., Estévez, E., \& Musitu, G. (in press) The relationships of adolescent school-related deviant behaviour and victimization with psychological distress: Testing a general model of the mediational role of parents and teachers across groups of gender and age. Journal of Adolescence.

Herrero, J., \& Meneses, J. (in press). Web-based short version of the perceived stress scale (PSS) and Center of Epidemiological Studies Depression (CES-D): A comparison to pencil and paper responses among Internet users. Computers in Human Behavior.

Hoge, R.D., Andrews, D.A., \& Leschied, A.W. (1996). An investigation of risk and protective factors in a sample of youthful offenders. Journal of Child Psychology and Psychiatry and Allied Disciplines, 37, 419-424.

Hymel, S., Bowker, A., \& Woody, E. (1993). Aggressive versus withdrawal unpopular children: Variations in peer and self-perceptions in multiple domains. Child Development, 64, 879-896.

Informe del Defensor del Pueblo. (2002). Violencia escolar: El maltrato entre iguales en la educación secundaria obligatoria [School violence: Maltreatment among peers in mandatory secondary education]. Madrid: Defensor del Pueblo.

Jackson, Y., \& Warren, J.S. (2000). Appraisal, social support, and life events: Predicting outcomes behavior in school-age children. Child Development, 71, 1441-1457.

Kiesner, J. (2002). Depressive symptoms in early adolescence: Their relations with classroom problem behavior and peer status. Journal of Research on Adolescence, 12, 463-478.

Kiesner, J., Poulin, F., \& Nicotra, E. (2003). Peer relations across contexts: Individual-network homophily and network inclusion in and after school. Child Development, 74, 1328-1343.

Kim, J.E., Hetherington, E.M., \& Reiss, D. (1999). Associations among family relationships, antisocial peers, and adolescents' externalizing behaviors: Gender and family type differences. Child Development, 70, 1209-1230.

Kupersmidt, J.B., Coie, J.D., \& Dodge, K.A. (1990). The role of poor peer relationships in the development of disorder. In S.R. Asher \& J.D. Coie (Eds.), Peer rejection in childhood (pp. 274-305). New York: Cambridge University Press.

Ladd, G.W. (1999). Peer relationships and social competence during early and middle childhood. Annual Review of Psychology, 50, 333-359.

Lambert, S.F., \& Cashwell, C.S. (2003). Preteens talking to parents: Perceived communication and school-based aggression. The Family Journal: Counseling and Therapy for Couples and Families, 11, 1-7.

Loeber, R. (1996). Developmental continuity, change and pathways in male juvenile problem behaviours and delinquency. In J.D. Hawkins (Ed.), Delinquency and crime: Current theories (pp. 28-67). New York: Cambridge University Press.

Lopez, C., \& Dubois, D.L. (2005). Peer victimization and rejection: Investigation of an integrative model of effects on emotional, behavioral, and academic adjustment in early adolescence. Journal of Clinical Child and Adolescent Psychology, 34, 25-36.

Matza, L.S., Kupersmidt, J.B., \& Glenn, M. (2001). Adolescents' perceptions and standards of their relationship with their parents as a function of sociometric status. Journal of Research on Adolescence, 11, 245-272.

McCubbin, H.I., \& Thompson, A.I. (1991). Family assessment inventories for research and practice. Madison: University of Wisconsin.

Miller-Johnson, S., Coie, J.D., Maumary-Gremaud, A., \& Bierman, K. (2002). Peer rejection and aggression and early starter models of conduct disorder. Journal of Abnormal and Child Psychology, 30, 217-230.

Moncher, F.J., \& Miller, G.E. (1999). Nondelinquent youths' stealing behavior and their perceptions of parents, school, and peers. Adolescence, 34, 577-591. 
Murray, C., \& Greenberg, M.T. (2001). Relationships with teachers and bonds with school: Social emotional adjustment correlates for children with and without disabilities. Psychology in the Schools, 38, 25-41.

Murray, C., \& Murray, K.M. (2004). Child level correlations of teacher-students relationships: An examination of demographic orientation characteristics, academia orientations, and behavioral orientations. Psychology in the Schools, 41, 751-762.

Musitu, G., \& García, F. (2004). Consecuencias de la socialización familiar en la cultura española [Consequences of family socialization in Spanish culture]. Psicothema, 16, 288-293.

Musitu, G., García, F., \& Gutiérrez, M. (1994). AFA: Autoconcepto Forma-A. [AFA: Self-concept. Type A]. Madrid: TEA Ediciones.

Parke, R.D. (2004). Development in the family. Annual Review of Psychology, 55, 365-399.

Parker, J.G., \& Asher, S.R. (1993). Friendship and friendship quality in middle childhood: Links with peer group acceptance and feelings of loneliness and social dissatisfaction. Developmental Psychology, 29, 611-621.

Parkhurst, J.T., \& Asher, S.R. (1992). Peer rejection in middle school: Subgroup differences in behaviour, loneliness and interpersonal concerns. Developmental Psychology, 28, 231-241.

Patterson, C.J., Kupersmidt, J.B., \& Griesler, P.C. (1990). Children's perceptions of self and of relations with others as a function of sociometric status. Child Development, 61, 1335-1349.

Pettit, G.S., Clawson, M.A., Dodge, K.A., \& Bates, J.E. (1996). Stability and change in peer-rejected status: The role of child behavior, parenting, and family ecology. Merrill-Palmer Quarterly, 42, 267-294.

Rabiner, D.L., Keane, S.P., \& MacKinnon-Lewis, C. (1993). Children's beliefs about familiar and unfamiliar peers in relation to sociometric status. Developmental Psychology, 29, 236-243.

Radloff, L.S. (1977). The CES-D scale: A self-report depression scale for research in the general population. Applied Psychological Measurement, 1, 385-401.

Reicher, S., \& Emler, N. (1985). Delinquent behavior and attitudes to formal authority. British Journal of Social Psychology, 3, 161-168.

Rubin, K.H., Bukowski, W., \& Parker, J.G. (1998). Peer interactions, relationships, and groups. In W. Damon \& N. Eisenberg (Eds.), Handbook of child psychology: Vol. 3. Social, emotional, and personality development (pp. 553617). New York: Wiley.

Sandstrom, M., \& Cramer, P. (2003). Girls' use of defense mechanisms following peer rejection. Journal of Personality, 71, 605-627.

Scholte, R.H.J., van Lieshout, C.F.M., \& van Aken, M.A.G. (2001). Perceived relational support in adolescence: Dimensions, configurations, and adolescent adjustment. Journal of Research in Adolescence, 11, 71-94.

Steinberg, L., \& Morris, A.S. (2001). Adolescent development. Annual Review of Psychology, 52, 83-110.

Thornberry, T.P. (1996). Empirical support for interactional theory: A review of the literature. In J.D. Hawkins (Ed.), Delinquency and crime: Current theories (pp. 198-235). New York: Cambridge University Press.

Verschueren, K., \& Marcoen, A. (2002). Perceptions of self and relationship with parents in aggressive and nonaggressive rejected children. Journal of School Psychology, 40, 501-522.

Welch, B.L. (1951). On the comparison of several mean values: An alternative approach. Biometrika, 38, 330-336.

Wentzel, K.R., \& Asher, S.R. (1995). The academic lives of neglected, rejected, popular, and controversial children. Child Development, 66, 754-763.

Werner, N.E. (2004). Maladaptive peer relationships and the development of relational and physical aggression during middle childhood. Social Development, 13, 495-514.

Wiesner, M., \& Windle, M. (2004). Assessing covariates of adolescent delinquency trajectories: A latent growth mixture modeling approach. Journal of Youth \& Adolescence, 33, 431-442.

Woodward, L.J., \& Fergusson, D.M. (1999). Childhood peer relationship problems and psychosocial adjustment in late adolescence. Journal of Abnormal Child Psychology, 27, 87-104.

Zakriski, A.L., \& Coie, J.D. (1996). A comparison of aggressive-rejected and nonaggressive-rejected children's interpretations of self-directed and other-directed rejection. Child Development, 67, 1048-1072.

Zettergren, P. (2003). School adjustment in adolescence for previously rejected, average, and popular children. British Journal of Educational Psychology, 73, 207-221. 